\title{
Małgorzata CZORNIK*
}

\section{TWÓRCY MIEJSKICH DÓBR WSPÓLNYCH}

\author{
CREATORS OF URBAN COMMON GOODS
}

\author{
Nr DOI: $10.25167 / \mathrm{sm} 2017.028 .03$ s. $43-58$
}

\begin{abstract}
ABSTRAKT: Tworzenie dóbr wspólnych jest przedmiotem działalności wielu grup użytkowników miasta. Ich wkład w budowaną w ten sposób atrakcyjność miejsca jest różny i zależy w dużym stopniu od indywidualnych skłonności do współpracy i integracji. Dobra wspólne są bowiem jednym z głównych rezultatów istnienia wspólnot, są przez nie wytwarzane. Bez inicjatyw społecznych zrzeszających osoby podzielające te same wartości, normy czy tożsamość nie można stworzyć podstawowych wyróżników tego rodzaju dóbr. Celem artykułu jest wskazanie różnych grup uczestników procesów tworzenia miejskich dóbr wspólnych oraz opisanie powiązań między nimi. Wśród wielu relacji, jakie mogą łączyć użytkowników miasta i sprzyjać powstawaniu wspólnot, na szczególną uwagę zasługują zależności ekonomiczne. Zainteresowanym zależy na maksymalizowaniu korzyści z lokalizacji dobra tworzonego na obszarze miasta. Wśród nich jako rodzaj korzyści aglomeracji występuje skłonność do współpracy wspólnotowej, która wzrasta, gdy motywowana jest szansą na uzyskanie szczególnego rodzaju dodatku, jakim są korzyści kolektywne. W miastach można je pozyskać znacznie łatwiej niż w innych miejscach.
\end{abstract}

SŁOWA KLUCZOWE: dobra wspólne, ekonomia dóbr wspólnych, użytkownicy miasta

ABSTRACT: Making of common goods is the subject of many groups of city users' activity. Their contribution to raising the attractiveness of places, which is co-created by them, depends on individual tendencies towards cooperation and integration. Common goods are one of the most important elements of communities' existence. They are produced by them, but can not be made without social initiatives which are incorporated in people concurring the same ideas, norms or local identity. The main objective of the paper is to point to different groups of participants who are involved in processes of creating urban common goods. It also describes many specific relations among them, fostering formation of urban communities. The special place in this sphere of dependencies is occupied by economic relationships. City users are interested in maximization of benefits which result from the localization of the goods in urban space. Among them, a tendency to community cooperation, as a type of economy of the agglomeration, increases being motivated by the chance to achieve the special addition, which are collective benefits. They are more likely to be gained in cities than in other places.

KEY WORDS: common goods, economy of the common good, city users

* Uniwersytet Ekonomiczny w Katowicach, e-mail: malgorzata.czornik@ue.katowice.pl 


\section{Wprowadzenie}

Popularyzowanie się zachowań mających na celu tworzenie wspólnot jest jedną z charakterystycznych cech ponowoczesności, w istotny sposób oddziałującej na realia społeczno-kulturowe, jakie aktualnie dominują. $W$ jej założeniach postuluje się zarówno zrzeszanie się jednostek w zbiorowości biorące odpowiedzialność za warunki, w których działają, jak i postrzeganie świata w bardziej holistycznym kontekście, uwzględniającym relacje wielopokoleniowe, sąsiedzkie, oparte na tożsamości miejsca czy stylu życia. Jednocześnie wszechobecny relatywizm poglądów i indywidualny z zasady konsumpcjonizm stanowią często o egoistycznej postawie użytkowników ograniczonych zasobów, którzy z trudem godzą się na wyrzeczenia dokonywane $\mathrm{w}$ imię wspólnego dobra i racji wynikających z konieczności tolerancji odmiennych wartości. W codziennych realiach wielu miast dochodzi do zderzania się różnych postaw, co skutkuje konfliktami, ale i refleksjami o potrzebie współpracy. Korzyści z zawierania kompromisów dotyczących interesów małych i dużych grup mogą być bardzo cenne, bo decydują o sukcesie starań zmierzających do zapewnienia spokojnych, bezpiecznych i trwałych warunków realizacji wszystkich miejskich przedsięwzięć rozwojowych. Rzadko można liczyć na jedność celów działania, ale profity możliwe do uzyskania z wzajemnej zgody przemawiają za konsolidacją wysiłków.

Skala lokalna czyni relacje użytkowników miast mniej anonimowymi. Ograniczona i znajoma przestrzeń, rozpoznane zasoby i uwarunkowania instytucjonalne tworzą szczególne środowisko współpracy podmiotów mających świadomość fizycznie bliskiej obecności innych. Jego wyjątkowość polega na istnieniu wielu łatwo dostępnych możliwości skutecznej odpowiedzi na oczekiwania społeczne, które chociaż wynikają głównie z różnorodności zainteresowań osób skupionych na obszarze miasta, są jednak także naznaczone jego specyfiką, wizerunkiem, rozmachem strategicznych działań, cechami stylu życia itp. Wspólnoty miejskie skupiają przede wszystkim mieszkańców, rzadziej osoby przybywające $\mathrm{z}$ innych miejsc i zainteresowane skorzystaniem $\mathrm{z}$ oferty miasta. W danym czasie stanowią charakterystyczny obraz zbioru jego użytkowników, będący w ścisłej zależności z ich potrzebami oraz ogólnymi realiami funkcjonowania. Cechy wspólnot są przejawem charakterystycznej dla nich „lokalności"1, gdyż zawierają wyróżniki „uczłowieczonego” przez nie fragmentu przestrzeni. Miejsca te są wybrane i traktowane jako własne w rozumieniu obszarów zagospodarowywania, obdarzania sentymentem czy umieszczania $\mathrm{w}$ nich trwałych śladów swojej obecności. A. Karwińska ((2008) pisze, iż postrzeganie przestrzeni jest zdeterminowane społecznie i kulturowo, co oznacza m.in. jego zależność

\footnotetext{
${ }^{1}$ Pojęcie to wywodzi się z łaciny (locus - miejsce, localis - miejscowy) i oznacza konkretne miejsce usytuowane w szerszej przestrzeni. Za: Piasecki 2009, s. 33-34.
} 
od zbiorowych uwarunkowań, takich jak perspektywy przyjęte przez grupę społeczną czy ingerencje osób narzucających obraz przestrzeni. Wspólnoty działające we fragmentach miejskiej przestrzeni dokonują jej wartościowania poprzez kontekst swoich celów. Wyznaczają je na podstawie istniejących miejskich problemów, zaś liczba wspólnot, rozmach ich działalności i zdolność kreowania zmian są społeczną odpowiedzią na skuteczność miejscowej polityki rozwoju.

\section{Dobro wspólne}

Dobro wspólne najczęściej definiuje się jako zasoby, do których istnieje otwarty dostęp, ale przy korzystaniu z których trzeba się liczyć z koniecznością rywalizacji². Ich cechy podlegają wyróżnieniu poprzez zestawienie z kategoriami dóbr publicznych, klubowych i prywatnych, stając się jednocześnie ich przeciwieństwem i uzupełnieniem ${ }^{3}$. Jako pojęcie ekonomiczne mają interesujące zastosowanie do określania aktywności podejmowanych z uwzględnieniem szczególnych motywacji. Są bowiem rezultatem istnienia wspólnot, które je wytwarzają zarówno jako skutek szeroko pojętej działalności produkcyjnej, będącej "przekształcaniem zasobów w wyroby" (Gornowicz, Romaniuk, Szczudełek 2014, s. 23), jak i reakcją na niezaspokajanie własnych potrzeb w stopniu wystarczającym, satysfakcjonującym czy uwzględniającym ambicje i subsydiarne ${ }^{4}$ chęci wzbogacenia walorów miejsc ważnych dla ich członków. Dobra wspólne powstają najczęściej dzięki szeroko rozumianym inspiracjom społecznym. Jak pisze D. Harvey (2012, s. 111): „,[...] nie są rodzajem rzeczy, zasobu czy nawet procesu społecznego, zdecydowanie bliżej im do plastycznej i niestabilnej relacji społecznej pomiędzy konkretną samookreśloną grupą społeczną i pewnymi aspektami środowiska". Mają związek przede wszystkim z tworzeniem dobrych warunków do życia i tym samym przestrzennie skupiają się głównie w miejscach lokalizacji zasobów mieszkaniowych. Są jednak również szczególnego rodzaju manifestacją postaw demokratycznych, wyrazem czynnego zainteresowania udziałem w gospodarowaniu obszarem miejskim, formą okazania praw do miasta i władzy nad jego fragmentami oraz wyróżnikiem podmiotów aspirujących do pozycji partnera dla wszystkich posiadających formalne prawa

\footnotetext{
${ }^{2}$ E. Ostrom pisze, że ograniczanie dostępu do nich nie jest niemożliwe, ale zbyt kosztowne (Ostrom 2013, s. 40).

${ }^{3}$ Dosyć szczegółową analizę dóbr wspólnych na tle innych kategorii dóbr zaprezentowano w pracy K. Marton-Gadoś 2014.

${ }^{4} \mathrm{~W}$ kontekście reakcji na działania władz, których ,[...] misją jest pobudzanie, podtrzymywanie, a w razie potrzeby, uzupełnianie wysiłków tych podmiotów które są niesamowystarczalne" (Millon-Delsol 1995, s. 8-9).
} 
do dysponowania lokalnymi zasobami. Pośrednio stanowią także część zbioru produktów miejskich, zwykle o ograniczonej dostępności rynkowej, ale w istotny sposób mogących oddziaływać na wizerunek miejsc. Bywają także czasami odpowiedzią na propozycje władz miasta, które przekazują grupom ważnych jego użytkowników wydzielone zasoby znajdujące się w ich kompetencjach, do zarządzania i wykorzystywania na własne cele, aby tym samym przekonać ich o znaczeniu dla miasta oraz atrakcyjności osadniczej lub gospodarczej miejskich lokalizacji.

W specyficzny sposób opisuje się i uzasadnia ekonomiczny kontekst istnienia dóbr wspólnych. Według P. Barnesa nie są bowiem nabywane czy kupowane, ale dane i dzielone z innymi osobami, co sprawia, że możemy je użytkować z tytułu przynależności do pewnej społeczności (za: Marton-Gadoś 2006, s. 3). Fakt uniezależnienia ich dostępności od realiów rynkowych czyni z nich we współczesnym świecie kategorię na tyle wyjątkową, że staje się przedmiotem refleksji jako alternatywa dla znanych form zaspokajania potrzeb społeczeństw, wobec zawodności funkcjonowania istniejących systemów gospodarczych. Polityka ekonomiczna wielu krajów, zmuszona liczyć się z zagrożeniami kryzysowymi i rewolucyjnymi, zainteresowana jest poszukiwaniem nowych sposobów zaspokajania popytu, stwarzających jednocześnie możliwości utrzymania spokoju społecznego. Bezpieczeństwo stanowi bowiem jeden z najbardziej pożądanych warunków atrakcyjności miejsc aktywności w ponowoczesnym świecie zalewanym falami emigrantów gospodarczych i uchodźców wojennych. Podstawą ich wędrówek jest brak bezpieczeństwa w miejscach, skąd pochodzą. Jednocześnie jednak w bogatych krajach, gdzie trafiają, stanowią zagrożenie dalszego sprawnego funkcjonowania systemów pomocy społecznej. Jeśli ich wydolność nie osiągnie progu zapewnienia minimum socjalnego dla wszystkich mieszkańców (nowych i dotychczasowych), może to grozić załamaniem się istniejącego porządku. Już dziś można obserwować wzrost poparcia dla nacjonalistycznych opcji politycznych w USA, Francji czy Holandii. Winą za wszelkie problemy społeczne obarcza się przybyszów, co czasami jest nawet częściowo uzasadnione, ale wiele z nich wydaje się wynikać raczej z błędów politycznych niż gospodarczych ${ }^{5}$.

W takich warunkach dobra wspólne jako ekonomiczna propozycja produkcyjna i konsumpcyjna mogą być w wielu sytuacjach na poziomie lokalnym całkiem skuteczną alternatywą zaspokajania potrzeb egzystencjalnych. Ich wytwarzanie oparte jest na skutkach tworzenia wspólnot, najczęściej budowanych w oparciu o zależności przestrzenne (np. sąsiedzkie), co przyczynia się do zmniejszania liczby miejscowych konfliktów i zawiązywania lepszych relacji międzyludzkich. Wymaga współpracy, angażuje dobrowolnie zdeklarowanych

\footnotetext{
${ }^{5}$ Emigranci to potencjalne zasoby pracy, a przybywają często do krajów znajdujących się w trudnej sytuacji demograficznej.
} 
członków wspólnoty, ale w pewien sposób jest jednak kontrolowane przez innych. Zachowania jednostek stają się podporządkowane wymaganiom wytwórczym zbiorowości i tym samym np. osoby niepracujące mogą tworzyć dobra wspólne, zamiast bezczynnie spędzać większość dnia. Będą "zatrudnione" przez wspólnotę, która raczej nie zapłaci im za pracę, ale zaoferuje pozytywną opinię i identyfikację społeczną. Uzyskają również prawo do użytkowania własnych wytworów, których konkretne przeznaczenie i cechy zależą od celu zawiązania się wspólnoty, ale zawsze w jakimś stopniu będą nim zainteresowani wszyscy jej członkowie. Wspólnoty powstają, aby likwidować braki poprzez wytwarzanie dóbr wspólnych będących alternatywą dla oferty rynkowej w sytuacjach braku środków na ich zakup lub innych możliwości zaspokojenia potrzeb wyższego rzędu w pożądany sposób. Dobra wspólne umożliwiają konsumpcję miejską, przyczyniając się do przyciągania bądź zatrzymywania użytkowników obszarów zurbanizowanych.

\section{Użytkownicy miasta jako członkowie wspólnot miejskich}

Miasto przyciąga nieskończoną liczbę różnych użytkowników. Każdy z nich chce korzystać $\mathrm{z}$ jego ofert, ale szczegółowy zakres zainteresowania ich zaletami zależy od wielu czynników, wśród których za najbardziej znaczące uznać należy indywidualne cele rozwojowe oraz potrzeby i pragnienia grupy, której dobre funkcjonowanie jest ważne dla jednostki (np. rodzina). Społeczny kontekst motywacji zachowań ekonomicznych nie przesądza o wyborze sposobów zaspokajania potrzeb. Najlepiej akceptowane i najłatwiejsze do realizacji są transakcje rynkowe. Przeprowadza się je w sklepach, które należą do tradycyjnych miejsc aktywności miejskich. Działalność handlowa w mieście nastawiona jest na zaspokajanie potrzeb różnych jego użytkowników, a w centrach handlowych i hurtowniach nawet $\mathrm{w}$ znacznie większym stopniu skierowana jest do przyjezdnych niż mieszkańców. Dla nich przygotowuje się za to większą część oferty dóbr publicznych, co uzasadnione jest oczywistym faktem, iż ich wytworzenie i dostarczenie finansowane jest ze środków budżetu miasta. Konsumpcja dokonywana $\mathrm{w}$ oparciu o inaczej niż rynkowo pozyskane dobra jest jednak ważna dla wielu jego użytkowników.

Skłonność podmiotów do korzystania z popularnych sposobów zaspokajania potrzeb nie przesądza o jednakowym dla wszystkich zainteresowaniu wchodzeniem w różne miejskie relacje. Rynek zapewnia anonimowość i ta jego cecha jest pożądana przez wielu klientów. Chcą oni pozyskiwać dobra i usługi bez konieczności angażowania się w jakiekolwiek dodatkowe aktywności. Płacą za towary, w cenę wliczając brak powiązań, i tym samym rekompensują swoją absencję $\mathrm{w}$ procesie wytwarzania nabywanego produktu. Zapłacili za to, że ktoś zrobił coś dla nich, za nich i bez ich udziału. Nie interesuje ich przede wszyst- 
kim zbiorowy kontekst wytwarzania dóbr, chociaż mogą interesować publiczne czy społeczne warunki ich konsumowania. Indywidualny charakter samego aktu konsumpcji jest oczywisty, ale rola otoczenia może istotnie przesądzać o dodatkowych korzyściach jego realizacji (Czornik 2012, s. 132). Świadomość istnienia współkonsumentów, osób oglądających, podziwiających, oceniających czy nawet zazdroszczących możliwości zaspokajania jakiejś potrzeby jest silną motywacją dla określonych zachowań konsumpcyjnych. Może determinować decyzję jednostki dotyczącą jej zaangażowania w aktywność grupy społecznej oferującej dostęp do pożądanego dobra lub warunków konsumpcji. Najczęściej sytuacja taka dotyczy konsumpcji dóbr klubowych, ale może się również odnosić do niektórych dóbr wspólnych, np. wytwarzanych w celu zaspokajania potrzeb towarzyskich we wspólnotach powstałych z osób dobieranych według kryterium wieku czy zainteresowań, gdzie każda osoba nieznajoma będzie od razu rozpoznana.

Wśród wielu grup użytkowników miast, wyróżnianych ze względu na ich znaczenie w procesach rozwoju lokalnego i zarządzania nim, jest kilka, które ze względu na swoje charakterystyczne cechy bardziej doceniają znaczenie korzyści wynikających $\mathrm{z}$ tworzenia wspólnot $\mathrm{i}$ współuczestniczenia $\mathrm{w}$ ich działaniach. Do grup tych zaliczyć można:

- Ogólnie ujmowany zbiór mieszkańców, będący wspólnotą osób żyjących w danym mieście, użytkujących jego zasoby mieszkaniowe i (poza nielicznymi wyjątkami) związanych z nim w szczególny sposób jako członkowie miejskiego samorządu terytorialnego;

- Społeczność lokalną, będącą szczególną wspólnotą stworzoną przez mieszkańców. Jest to „[...] grupa o wielu interesach, w pewnym stopniu heterogeniczna, której jedność pochodzi z wzajemnych zależności, jakie zachodzą między grupami dążącymi do realizacji różnych specjalnych interesów, ale działającymi na pewnym wspólnym obszarze" (Weber za: Turowski 1994, s. 215). Jest rezultatem wieloletniego (nawet wielowiekowego) procesu integracji opartej na wspólnym miejscu, skutkującego uzgodnieniem wśród jej członków wspólnych wartości i celów. Jej istnienie wymaga wielopokoleniowych relacji sąsiedzkich, a najczęściej wymieniane atrybuty to także powszechnie akceptowane normy, zwyczaje, tradycje oraz ograniczona liczba aktorów i szczególnego rodzaju autarkia (Szczepański 1993). Społeczności lokalne są rzadkością w realiach wielkomiejskich, ale zdarzają się $\mathrm{w}$ mniejszych miastach i dzielnicach, zwykle tych, które kiedyś stanowiły osobne miejscowości;

- Władze lokalne, czyli wspólnotę mieszkańców jednostki terytorialnej, stanowiących z mocy prawa wspólnotę samorządową (Ustawa...) oraz ich reprezentację, czyli radę gminy i burmistrza (prezydenta). Posiadają osobowość prawną i wyznaczone kompetencje, co określa ich szczególną pozycję wśród wytwórców dóbr wspólnych, jako właścicieli nieruchomości i innych zasobów lokalnych; 
- Organizacje społeczne, stanowiące wspólnoty złożone z mieszkańców miasta i osób z zewnątrz lub innych podmiotów zainteresowanych formalnym współdziałaniem $\mathrm{w}$ celu realizacji określonych celów. Powstają przede wszystkim jako społeczna odpowiedź na potrzeby, których zaspokojenie wymaga współpracy wielu ludzi dobrowolnie zrzeszonych. Mogą działać wiele lat i być ważnym elementem miejscowego wizerunku. Są podstawą wspólnotowej organizacji życia w danej miejscowości, w tym grupami nacisku czy ważnymi partnerami społecznymi do uzgadniania decyzji rozwojowych z władzami gminy, jako reprezentanci grup mieszkańców aktywnie zaangażowanych $\mathrm{w}$ pożądane zmiany. Najczęściej działają w takich dziedzinach jak: kultura, rekreacja, sport i edukacja;

- Zrzeszenia nieformalne, stanowiące wspólnoty tworzone przez osoby zainteresowane współpracą $\mathrm{w}$ celu osiągnięcia indywidualnych korzyści. Czasami powstają jako spontaniczne inicjatywy, będące reakcją na powstałe zagrożenie lub niechciany zewnętrzny impuls rozwojowy. Cechują się dużą anonimowością członków grupy, często krótkotrwałością lub zmiennością intensywności działalności. Do tworzonych przez nie dóbr wspólnych ich członkowie podchodzą egoistycznie, ale doceniają możliwość skorzystania ze skutków zbiorowych wysiłków;

- Jednostki gospodarcze, przede wszystkim te, które są silnie związane z miastem, czyli działające tylko na jego obszarze bądź posiadające tam swoje zarządy czy najważniejsze wydziały. Ich udział w tworzeniu wspólnot jest ściśle związany z realiami działalności na danym obszarze i współpracują najczęściej dla osiągnięcia korzyści aglomeracji lub wspólnej obrony przed zagrożeniami. W ramach drugiego celu czasami są skłonne tworzyć szczególne dobro wspólne, za jakie można uznać lobbing gospodarczy, w lokalnym kontekście często związany z gospodarowaniem przestrzennymi zasobami gminy, $\mathrm{w}$ tym decyzjami lokalizacyjnymi. W takim kontekście za wspólnotę celową inspirowaną indywidualnymi interesami firm - członków grupy można uznać np. klastry;

- Jednostki zewnętrzne, głównie władze publiczne wyższych szczebli (powiatowe, wojewódzkie, państwowe) oraz instytucje o zasięgu ponadlokalnym, często inspirowane w swej działalności skutkami powiązań zewnętrznych. Ich zainteresowanie tworzeniem lub współpracą w ramach wspólnot związane jest z miejskimi uwarunkowaniami realizacji własnych celów. Posiadają możliwości prawne i środki, aby finansować przedsięwzięcia, ale w odróżnieniu od jednostek gospodarczych zwykle potrzebują zaangażowania społecznego wyrażającego poparcie dla promowanych idei oraz będącego uzasadnieniem dla celów i zasad wydatkowania publicznych środków.

Zainteresowanie grupy użytkowników miasta wytwarzaniem dóbr wspólnych często uwarunkowane jest możliwościami angażowania się w różne inicjatywy społeczne. Nie są one takie same, gdyż podmioty publiczne z założenia powinny każdą decyzję uzasadniać względami przydatności zbiorowej, zaś jed- 
nostki gospodarcze wchodzą w relacje pod warunkiem zyskowności przedsięwzięć. Dla indywidualnego członka wspólnoty uczestnictwo w jej działaniach ma przede wszystkim wymiar szansy na otrzymanie czegoś, czego sam nie mógłby uzyskać bądź zdobyłby to zbyt dużym kosztem. Korzyści przynależności stanowią główny argument tworzenia wspólnot. Spontaniczne zrzeszenia powstają częściej w momentach pojawienia się zagrożenia dla istnienia dotychczasowych warunków zaspokajania potrzeb, jednak wspólnoty to forma znacznie bardziej trwała i znacznie ważniejsza $\mathrm{w}$ oddziaływaniu na realia miejskie. Nie każda inicjatywa wspólnotowa staje się motorycznym czynnikiem rozwoju miasta, ale wiele $\mathrm{z}$ nich, jako przedsięwzięcia inspirowane oddolnie, bardzo dobrze wpisuje się w oczekiwania społeczne. Popierający je użytkownicy miasta mogą stać się lokalną grupą nacisku, z którą muszą się liczyć wszyscy podejmujący kluczowe decyzje dotyczące zmian w mieście.

\section{Model zależności}

Ustalenie relacji pomiędzy podmiotami, które $\mathrm{w}$ realiach miejskich mogą być zainteresowane tworzeniem dóbr wspólnych, wymaga przyjęcia generalnego założenia determinującego takie działania. Jest nim przekonanie, że dobra wspólne tworzą tylko wspólnoty. Ponieważ są to zarówno „[...] zbiorowości oparte na silnych więziach społecznych, tradycji i stosunkach osobistych" (Goodman 1992), jak i „,[...] sieci powiązanych wzajemnie relacji międzyludzkich, zabarwionych elementem emocjonalnym oraz pewnego zobowiązania wobec podzielanych wartości, norm, znaczeń, historii i tożsamości" (Etzioni za: Gawkowska 2004, s. 567), ich obecność w mieście nie jest oczywista. Stanowią raczej przedmiot starań wszystkich zainteresowanych rozwojem miasta, którzy są świadomi ich zalet oraz znaczenia. Są rzadkością nie tyle co do ich liczby (niekoniecznie skorelowanej z wielkością miasta), ile trwałości istnienia. Dotyczy to zwłaszcza wspólnot tworzonych dla podejmowania inicjatyw użytkowania elementów zagospodarowania przestrzennego miasta wymagających dłuższego zaangażowania, $\mathrm{w}$ przeciwieństwie do inicjatyw wspólnotowych inspirowanych zewnętrznymi czynnikami, np. przepisami prawnymi stwarzającymi zagrożenia istnienia dotychczasowych funkcji miejskich poprzez inne zasady ich finansowania. Miasta się zmieniają, a ich użytkownicy nieustannie poszukują okazji do lepszego zaspokajania swoich potrzeb. W porównaniu z mieszkańcami terenów wiejskich, których działalności rolnicze czy leśne związane są z warunkami środowiska przyrodniczego i dla uzyskania wymiernych korzyści powinny być podejmowane przez dziesiątki lat, miejska społeczność stale ewoluuje, inspirowana postępem technologicznym, nowymi trendami kulturowymi czy nawet decyzjami politycznymi. Zachowania jej członków znacznie rzadziej dążą do tworzenia trwalszych relacji. Szczególnego rodzaju konserwatyzm, 
który pomaga na wsiach radzić sobie z brakiem zasobów czy odległościami, w mieście może być postrzegany jako hamulec modernizacji, bariera utrudniająca doskonalenie produkcji i konsumpcji w oparciu o nowe rozwiązania, ograniczenie innowacyjności. Na obszarach miast mieszka wielu ludzi i funkcjonuje wiele podmiotów, tak iż łatwo można kogoś spotkać, zdobyć potrzebne zasoby, skopiować pomysły. Tworzenie miejskich wspólnot nie jest wymuszane egzystencjalnymi potrzebami łączenia wysiłków, a w takich warunkach skłonność do współpracy wymaga mniej oczywistego przekonania o istnieniu szans na uzyskanie korzyści z niej. Są one raczej dodatkowymi impulsami rozwojowymi, pomagającymi nie tyle przetrwać, co doskonalić warunki życia. Miasta, stwarzając szanse na tworzenie miejskich wspólnot, oferują możliwości realizacji ambitniejszych dóbr wspólnych i tym samym pozyskania produktów oryginalnych, unikalnych, o ponadprzeciętnej wartości itp.

Aby powstały takie dobra, potrzebne są wspólnoty, które nie tylko będą realizować własne cele, ale także, jako zbiór szczególnych użytkowników miasta, przyczynią się do tworzenia lepszych realiów jego funkcjonowania. Ich wzajemne powiązania $\mathrm{w}$ znaczący sposób mogą wzbogacić system miejski, stworzyć nową jakość oferty lokalizacyjnej, miejsce aktywności społecznej umożliwiającej pozyskanie cennych wartości ${ }^{6}$. Zbiór relacji składających się na podstawowy model zależności międzypodmiotowych w procesach tworzenia dóbr wspólnych (rys. 1) obejmuje następujące zależności:

1. Mieszkańcy $\rightarrow$ wspólnota. Jest to najbardziej oczywista relacja podmiotów zainteresowanych istnieniem dóbr wspólnych. Mieszkańcy miasta chcą do-

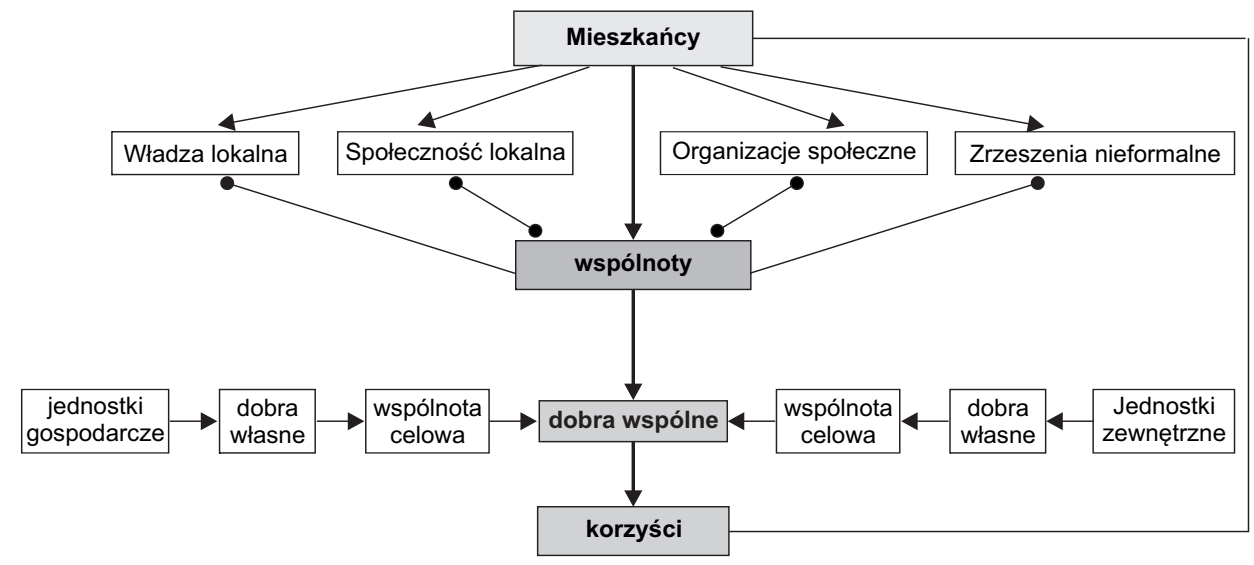

Rys 1. Model tworzenia dóbr wspólnych

Źródło: opracowanie własne.

\footnotetext{
${ }^{6} \mathrm{~W}$ rozumieniu ich potencjalnego znaczenia dla rozwoju, definiowanego jako „kreowanie nowych wartości" (Klasik 1996).
} 
brych warunków do życia i jeśli czegoś im brakuje, są skłonni rozważyć możliwość wytworzenia dóbr zaspokajających potrzeby. Ich zaangażowanie może wynikać zarówno z egoistycznych motywacji konsumpcyjnych, jak i bardziej ambitnych pobudek społecznych, związanych z wyznawanymi poglądami, przyjmowanymi zasadami, akceptowanymi ideałami itp. Mnogość rodzajów potencjalnych wspólnot, jakie mogą zawiązać mieszkańcy miast, uniemożliwia ich precyzyjne wyróżnienie. Każdy pomysł znajdujący zwolenników może się stać celem działania wspólnoty. Uwzględniając duże zróżnicowanie cech mieszkańców miast (wiek, zawód, wykształcenie, pochodzenie itp.), zbiór wspólnot miejskich może być bardzo bogaty. Znaczna większość z nich mieści się ideowo w wizerunku miasta, ale zdarzają się wspólnoty tworzone np. przez niezasymilowanych imigrantów czy osoby inspirowane zewnętrznymi pomysłami, których cele integrujące nie mieszczą się w utrwalonym i powszechnie zaakceptowanym zbiorze wartości, nie przystając do specyfiki lokalnej.

2. Wspólnota $\rightarrow$ dobra wspólne. Ta relacja wynika z przyjętego wcześniej założenia o konieczności istnienia wspólnoty jako wytwórcy dobra wspólnego. Tylko świadome zaangażowanie jej członków pozwala uzyskać przedmioty zaspokajające potrzeby, które będą zawierały w swej ofercie możliwość uzyskania korzyści. Wspólnoty powstają, aby tworzyć dobra. One są celem aktywności przez nie prowadzonej. Dobra wspólne mogą być materialne i niematerialne, mogą wynikać ze zgodnej i równej współpracy wszystkich jej członków lub być tworzone dzięki różnemu jednostkowemu zaangażowaniu. Bywają oryginalne lub są znanym i często spotykanym rezultatem relacji międzyludzkich. Są tym bardziej pożądane, im trudniej pozyskać dobra rynkowe lub publiczne, szczególnie takie, których braki ograniczają zaspokajanie potrzeb podstawowych. W takich warunkach wspólnoty tworzące dobra bywają jedynym sposobem likwidacji braków, w pewnym sensie subsydiarnie zastępując funkcje władz publicznych wobec niesamodzielnych jednostek.

3. Dobra wspólne $\rightarrow$ korzyści. Każde dobro służy zaspokajaniu potrzeb. Wytwarza się je, aby osiągnąć korzyści, które jednocześnie motywują do aktywności. Dobra wspólne są rodzajem dóbr, więc tworzy się je, mając na względzie czyjeś braki. Ich cechą jest oryginalny komponent, jaki zawierają, to jest wkład społeczny grupy je wytwarzającej, mający wymiar możliwości uzyskania korzyści kolektywnych. Można je zdefiniować jako korzyści wynikające z istnienia zbiorowości, które konsumowane są przez jednostkę w większości przypadków będącą częścią tej zbiorowości. Ich wyróżnikiem nie jest osoba odbiorcy ani sposób konsumpcji (poza szczególnymi wyjątkami), ale warunki powstawania. Są bowiem rezultatem synergii indywidualnych zachowań członków wspólnoty, postrzeganym jako pożądany z punktu widzenia uczestnictwa jednostki w życiu społecznym. Mogą tym samym być celem współpracy w realizacji takich zamiarów, których nie można osiągnąć staraniami jednej osoby, ale także wtedy, gdy potrzebna jest jedność opinii, poglądów czy przekonań, będąca siłą 
zdolną wesprzeć pożądane działania czy powstrzymać niechciane. Współcześnie częściej jednak wydają się być alternatywą zaspokajania potrzeb wyższego rzędu, związanych z rozwojem osobowym, społeczną aktywnością czy prestiżem.

4. Korzyści $\rightarrow$ mieszkańcy. Każda zmiana relacji miejskich zmienia miasto jako całość, a tym samym warunki życia w nim. Mieszkańcy zawsze odczują w jakimś stopniu odmienność realiów. W pewnym sensie wszystkie zmiany są dla nich. Miasto jako jednostka osadnicza realizuje przede wszystkim cele nakierowane na tworzenie dobrych warunków bytowania. Korzyści jakiejkolwiek grupy jego użytkowników muszą być skorelowane z interesami mieszkańców. Jeśli nie są, to nie uzyskają ich akceptacji i w sposób oczywisty zostaną z miasta usunięte. Tak przynajmniej powinno się stać zgodnie z istnieniem teoretycznych zasad organizacji miast. W praktyce bywa, że narzuca się mieszkańcom rezultaty działalności różnych osób, firm i wspólnot powstających z inspiracji zewnętrznymi, pozamiejskimi inicjatywami. Mnogość konfliktów przestrzennych, w których jedną stroną jest wspólnota mieszkańców broniąca swoich miejsc, a drugą podmiot, grupa interesariuszy lub wspólnota posiadająca odmienne cele, potwierdza rangę społecznych protestów. Dobra wspólne, z których korzyści uzyskują członkowie wspólnoty, ale ich część (choćby tylko udział $\mathrm{w}$ zbiorze pozytywnych składowych wizerunku miasta) dostaje się wszystkim mieszkańcom, są pożądaną i wspieraną formą relacji.

5. Mieszkańcy $\rightarrow$ społeczność lokalna $\rightarrow$ wspólnota. Podstawowe atrybuty społeczności lokalnych $\mathrm{w}$ zasadzie wykluczają ich istnienie $\mathrm{w}$ miastach, gdyż stałe dążenie do unowocześniania jest w opozycji do konserwatyzmu tego typu wspólnot. Mieszkańcy miast lubią zmiany, a mniej doceniają trwałość wartości. Jeśli już skłonni są tworzyć takie wspólnoty, to przynależność do nich ma charakter poważnego zobowiązania dotyczącego stylu życia i wielu zachowań społecznych. Nie stać na to np. członków klasy metropolitarnej, którzy się terytorialnie nie zakorzeniają i nie dbają o akceptację sąsiadów. Jednocześnie dobro wspólne, będące rezultatem działalności społeczności lokalnej, jest najlepiej terytorialnie zakorzenioną odmianą takiego dobra. Inicjatywa żadnej innej wspólnoty $\mathrm{w}$ tak dużym stopniu nie uwzględnia cech miejsca, ujmowanego jako przestrzenne odniesienie potrzeb osadniczych. Wytworzenie dóbr wspólnych przez członków społeczności lokalnej jest również najłatwiejsze co do konieczności przekonania o słuszności podejmowania wysiłków. Społeczności uzgadniają hierarchie wartości i dobra wspólne mają w nich swoją rangę, jako służące osiąganiu określonych celów. Są to prawie idealne wspólnoty (minusem może być wspomniana ostrożność wobec nowości i ksenofobiczne traktowanie obcych), zdolne wytwarzać najbardziej pożądane dobra wspólne, jednak jako grupy miejskie są wyjątkowo rzadkie, długo powstają, wolno ewoluują i tym samym stanowią raczej szczególny przypadek niż powszechnie występujące formy samoorganizacji osadniczej miasta. 
6. Mieszkańcy $\rightarrow$ władza lokalna $\rightarrow$ wspólnota. Władze miasta są rezultatem demokratycznych wyborów mieszkańców, którzy podejmują rozstrzygnięcia w głosowaniu powszechnym lub za pośrednictwem organów gminy. Te zaś są najbardziej czynnym użytkownikiem miasta, jednocześnie inicjując pożądane zmiany i ograniczając skutki występowania negatywnych procesów i zjawisk. Władze (radni, burmistrz) nie są wspólnotą, ale formalnym reprezentantem wspólnoty. Ich szczególna pozycja w procesach powstawania wspólnot i dóbr wspólnych wynika z faktu, że są dysponentami wielu lokalnych zasobów. Własność komunalna jest przedmiotem zarządzania, które realizują i tym samym określają realia działalności wszystkich grup na obszarze miasta. Wiele $\mathrm{z}$ nich terytorialnie działa na terenach komunalnych i korzysta $\mathrm{z}$ gminnego wsparcia. Podejmowane przez nie inicjatywy wytwarzania dóbr wspólnych zgodne są z polityką władz. Raczej realizują jej cele, niż stanowią wyraz oddolnych potrzeb społecznych. Często powstanie takich wspólnot jest inspirowane przez władze miasta, które szukają chętnych do zaangażowania się w określone działania. Podstawą inspiracji bywa chęć lub techniczna konieczność zagospodarowania konkretnego miejsca. W ramach postulowanych idei partycypacji obywatelskiej zachęca się do podejmowania aktywności grupy mieszkańców potencjalnie zainteresowanych korzyściami możliwymi do uzyskania z dóbr wspólnych wytwarzanych w oparciu o zasoby przekazane im (jako wspólnocie) przez władze miasta. Nie można deprecjonować zalet takiej ścieżki wspierania miejskiej wspólnotowości, gdyż wydaje się najłatwiejsza do zrealizowania poprzez inkubowanie inicjatyw społecznych, tak aby udało im się przetrwać trudne początki i rozwinąć $\mathrm{w}$ pełni swoje możliwości.

7. Mieszkańcy $\rightarrow$ organizacje społeczne $\rightarrow$ wspólnota. Organizacje społeczne są popularną formą zrzeszania się tych mieszkańców, którzy są zainteresowani zaspokajaniem potrzeb angażowania się $\mathrm{w}$ życie miasta poprzez udział $\mathrm{w}$ strukturach formalnych. Zapewniają one zdobycie znaczenia $w$ realiach miejskich poprzez uczestniczenie $\mathrm{w}$ działalności statutowej organizacji, ale zdarza się, że tworzone przez nią dobra wspólne mają większą liczbę konsumentów. Miejski chór śpiewa dla własnej przyjemności, ale może uświetnić lokalne wydarzenia. Stowarzyszenie osób zainteresowanych uprawianiem sportu, gotowaniem, szydełkowaniem czy jakimkolwiek wspólnym hobby wytwarza dobra wspólne identyfikowane jako miejskie produkty. Zaletą organizacji społecznych jako wspólnot mieszkańców jest ich trwałość, znacznie dłuższa niż nawet najliczniejsze inicjatywy nieformalne, ale krótsza niż istnienie społeczności lokalnych. Te powstają $\mathrm{w}$ oparciu o miejsce, czyli fragment przestrzeni $\mathrm{w}$ pewnym sensie wieczny, zaś organizacje skupiają członków pod warunkiem istnienia celu działalności, który odpowiada aktualnym warunkom rozwoju cywilizacyjnego i cech oferty publicznej. Jeśli płynące z niego korzyści staną się osiągalne poprzez dobra prywatne (własny telewizor) czy publiczne (otwarty koncert w miejscu dostępnym dla wielu osób), to taka forma integracji społecznej może 
stracić na znaczeniu. Wydaje się jednak, że zawsze będzie zainteresowanie spotkaniami z innymi ludźmi i korzyściami kolektywnymi oferowanymi przez zorganizowaną wspólnotę $e^{7}$.

8. Mieszkańcy $\rightarrow$ zrzeszenia nieformalne $\rightarrow$ wspólnota. Takie relacje są przede wszystkim spontanicznymi inicjatywami uzupełniającymi oferty władz miejskich bądź reakcją na zaniechania ich aktywności. Mogą przybierać formę regularnych spotkań, z czasem formalizujących działalność lub charakteryzujących się zróżnicowaną frekwencją. W skrajnej formie mogą przerodzić się nawet w syndromy protestacyjne (np. NIMBY), podejmowane, aby doprowadzić do zmiany decyzji. Inspiracjami powstawania wspólnot o charakterze zrzeszeń nieformalnych są istniejące realia, gdyż w odróżnieniu od innych opisanych sposobów tworzenia wspólnot te powstają przede wszystkim ex post. Najpierw następuje wydarzenie, zmiana, zagrożenie, szansa itp., które przyciągają ludzi do określonego miejsca. Wystarczy lider lub klika osób mocno zaangażowanych $\mathrm{w}$ reakcję na pierwotny bodziec, aby skłonić innych do działań. Dobra wspólne wytwarzane przez takie wspólnoty są najczęściej krótkotrwałe w ich konsumpcji, chociaż ich skutki bywają dla miasta bardzo poważne. Mogą zatrzymać inwestycję, wymusić realizację funkcji (np. obrona szkoły przed likwidacją, jakiej podejmuje się wspólnota młodzieży i rodziców) czy spowodować zmiany zagospodarowania. Nie do przecenienia jest także znaczenie takich wspólnot w rozwijaniu idei społeczeństwa obywatelskiego.

9. Jednostki gospodarcze $\rightarrow$ dobra $\rightarrow$ wspólnota celowa. Pod pojęciem wspólnoty celowej tworzonej z inicjatywy jednostek gospodarczych $\mathrm{w}$ proponowanym schemacie tworzenia dóbr wspólnych należy rozumieć sieć powiązań firm tworzoną, aby osiągnąć zamierzone cele. Jest to wspólnota osób oparta na relacjach międzyludzkich i jedności interesów gospodarczych. W porównaniu z opisanymi wcześniej wspólnotami takie relacje są raczej jednorazowe. Istnieją do czasu realizacji celu. Rozpadają się bez zbędnych formalności i za całkowitą akceptacją wszystkich członków wspólnot. Działalność wspólnoty może jednak trwać przez pewien czas, nawet kilka lat, co wynika z rodzaju relacji gospodarczych czy wymagań technologicznych. Uczestnictwo w niej może być na równych prawach wszystkich członków, ale także z szerszymi kompetencjami większych firm lub znaczniejszych finansowo udziałowców. W odróżnieniu od wspólnot tworzonych przez mieszkańców wkładem uczestników wspólnot celowych są ich prywatne (firmowe) dobra, które stają się zasobami do tworzenia dóbr wspólnych przez wszystkich członków wspólnoty. Ich przekazanie do dyspozycji wszystkich ma charakter "wpisowego" i czyni wiarygodną ofertę zaangażowania. Dobra wspólne, które tworzą, nie są równo

\footnotetext{
${ }^{7} \mathrm{~Np}$. mecz czy inne wydarzenie sportowe można oglądać zarówno samemu w domu, jak i w strefie kibica, wśród innych dopingujących tej samej drużynie, posiadających charakterystyczne wyróżniki wspólnoty kibiców, w tym formalne członkostwo w stowarzyszeniu.
} 
konsumowane, ale w relacji do wkładów, chociaż każdy z członków wspólnoty ma jakiś udział w konsumpcji korzyści kolektywnych.

10. Jednostki zewnętrzne $\rightarrow$ dobra $\rightarrow$ wspólnota celowa. Podobnie jak opisane powyżej inicjatywy integracyjne jednostek gospodarczych, także wspólnoty celowe jednostek zewnętrznych, takich jak władze publiczne innych szczebli, pozamiejskie organizacje i instytucje, czy wspólnoty tworzone przez przyjezdnych, inspirowane są przekazaniem na cele wspólnoty dóbr prywatnych. Są najczęściej sieciami powiązanych wzajemnie relacji międzyludzkich opartych na zobowiązaniach wobec przyjętych celów. Ich trwałość zależy od cech celów i czasu niezbędnego do ich osiągnięcia. Niektóre instytucje publiczne przyjmują zadania bezterminowe, co zacieśnia skalę współpracy, ale rzadko przyczynia się do tworzenia wspólnot. Te powstają, aby zrealizować cel. W odróżnieniu od wspólnot celowych jednostek gospodarczych sukces konsumpcji wytwarzanych przez wspólnotę dóbr wspólnych nie musi mieć charakteru zysku finansowego ani żadnej innej komercyjnej identyfikacji. Cele mogą być społeczne, a wspólnota jednostek łączy się, aby skuteczniej je osiągnąć i np. koordynować działania różnych członków, wzajemnie się uzupełniając, likwidować konflikty kompetencji, unikać marnotrawstwa dóbr stanowiących zasoby dla tworzenia dóbr wspólnych. Takie wspólnoty mogą powstawać w sytuacjach kryzysowych, np. powodzi, trzęsienia ziemi, ale i koniunkturalnego załamania gospodarki lokalnej, tragicznego bezrobocia czy wyczerpania surowców naturalnych.

11. Wspólnota celowa $\rightarrow$ dobro wspólne. Ta relacja określa prostą zależność, że wspólnoty tworzone, aby zrealizować konkretny cel, także tworzą dobra wspólne. Ich zdefiniowanie wymaga precyzyjnego odróżnienia od kategorii dóbr klubowych. Wydaje się bowiem, że jeśli członkostwo we wspólnocie wymaga zaangażowania prywatnych dóbr, to rezultaty działalności wspólnoty będą przeznaczone tylko dla zaangażowanych. Jeśli mają charakter dóbr wspólnych, to może je konsumować każdy. Tworzący wspólnoty celowe liczą się z możliwością pojawienia się "gapowiczów”, chętnych do skorzystania z dóbr wspólnych, dopuszczając możliwość częściowej ich utraty. Koszty dopilnowania, aby korzyści stały się udziałem tylko członków wspólnoty, są zbyt duże lub wartość straty zbyt mała. Często również mają one tak wyspecjalizowany charakter, że w sąsiedztwie nie ma zbyt wielu potencjalnie zainteresowanych na darmowe dołączenie się do rezultatów osiągania cudzych celów.

Przedstawiony zbiór relacji, jakie można wyróżnić w procesie analizowania tworzenia miejskich dóbr wspólnych, ma charakter autorski. Stanowi propozycję analizowania zależności wewnątrzmiejskich z uwzględnieniem generalnego celu, jakim jest powstawanie wspólnot i rezultatów ich działalności. Przedstawiona propozycja obejmuje wszystkie najważniejsze grupy użytkowników miasta zaangażowanych $\mathrm{w}$ tworzenie społecznych realiów jego funkcjonowania. Większa szczegółowość opisu relacji wymagałaby wyróżnienia mniejszych grup i bardziej drobiazgowego ustalenia ich cech oraz znaczenia dla miasta. Po- 
między wszystkimi osobami, grupami, dobrami i korzyściami występować mogą z pewnością jeszcze inne rodzaje zależności niezwiązanych z potencjalnym zaangażowaniem $\mathrm{w}$ tworzenie dóbr wspólnych, których omówienie nie jest przedmiotem tego artykułu.

\section{Podsumowanie}

Istnienie miejskich wspólnot jest rezultatem zawiązywania się różnego rodzaju więzi, opartych zarówno na celach, jak i emocjach. Mogą one angażować wiele miejskich zasobów w tworzenie dóbr, przy czym zwykle nie istnieją żadne formy nacisku na użytkownika miasta, aby dokładał swoje zasoby do oferty tworzonej we współpracy z innymi. D. Bollier podkreśla, że dobra wspólne nie są dobrami rzeczowymi czy też dobrami uniwersalnymi, a jest to raczej pojęcie opisujące rodzaj trwałych, dynamicznych więzi społecznych zawiązywanych w celu zarządzania różnego rodzaju zasobami, dodając, że nie ma wspólnych dóbr bez współużytkowania (za: Marton-Gadoś 2014). Uczestnictwo we wspólnocie jest najważniejszym celem jej zawiązywania, gdyż pozwala na wytwarzanie dóbr, opierających swoje zalety na generowanych przez nią korzyściach kolektywnych. Istnienie wspólnot miejskich przekłada się na atrakcyjność miasta, które mając takie formy współpracy swoich użytkowników, postrzegane jest jako miejsce bezpiecznych, trwałych i cennych relacji. Posiadanie takich elementów wizerunku zawsze się opłaca.

\section{Bibliografia}

Czornik M., 2012, Konsumpcja miejska. Ekonomiczne refleksje nad ewoluowaniem funkcji miejskich, Uniwersytet Ekonomiczny, Katowice.

Gawkowska A., 2004, Komunitaryzm, [w:] Słownik społeczny, red. B. Szlachta, Wydawnictwo WAM, Kraków.

Goodman N., 1992, Wstęp do socjologii, Wydawnictwo Zysk i S-ka, Poznań.

Gornowicz M., Romaniuk K., Szczudełek G., 2014, Ekonomika produkcji, Uniwersytet Warmińsko-Mazurski, Olsztyn.

Harvey D., 2012, Bunt miast. Prawa do miasta i miejska rewolucja, Wydawnictwo Bęc Zmiana, Warszawa.

Karwińska A., 2008, Gospodarka przestrzenna. Uwarunkowania społeczno-kulturowe, Wydawnictwo Naukowe PWN, Warszawa.

Klasik A., 1996, Zarzadzanie rozwojem lokalnym, [w:] Zarządzanie rozwojem gminy w zespołach miejsko-przemysłowych, red. F. Kuźnik, Akademia Ekonomiczna, PTE, Katowice.

Marton-Gadoś K., 2014, Dobra wspólne - metodologia badania zjawiska, „Myśl Ekonomiczna i Polityczna" 4(47), s. 40-72, www.bollier.org/new-to-the-commons (dostęp 30 lipca 2014).

Millon-Delsol Ch., 1995, Zasada pomocniczości, Znak, Kraków.

Ostrom E., 2013, Dysponowanie wspólnymi zasobami, Wolters Kluwer, Warszawa.

Piasecki A.K., 2009, Samorząd terytorialny i wspólnoty lokalne, Wydawnictwo Naukowe PWN, Warszawa. 
Szczepański M.S., 1993, System światowy: między globalizmem i lokalizmem, [w:] Społeczności lokalne i rozwój lokalnej demokracji, red. M.S. Szczepański, Centrum Naukowe „Sokrates”, Agencja Wydawnicza „Domino", Katowice.

Turowski J., 1994, Socjologia. Wielkie struktury społeczne, Towarzystwo Naukowe KUL, Lublin. Ustawa o samorządzie gminnym z dnia 8 marca 1990 r., DzU z 2001 r. Nr 142, poz. 1591 ze zm. 